\title{
Próba przebudowy układu województw z wykorzystaniem sieci ośrodków regionalnych
}

\author{
An attempt at restructuring Poland's voivodship system on the basis of \\ a network of regional centers
}

\author{
LUKASZ ZABOROWSKI \\ Instytut Sobieskiego, 00-029 Warszawa, Nowy Świat 27 \\ lukasz.zaborowski@sobieski.org.pl
}

\begin{abstract}
Zarys treści. W opracowaniu zaproponowano przebudowę podziału terytorialnego na szczeblu województw na podstawie wybranych prostych czynników. Procedurę podzielono na dwa etapy: budowę regionów przez przyporządkowanie powiatów do ośrodków regionalnych oraz budowę województw w drodze wzajemnego powiązania regionów. W dyskusji podjęto dylematy wynikające z rozbieżności więzi funkcjonalnych i kulturowych, ich zmienności w czasie oraz ze zniekształcenia oglądu przestrzeni przez obowiązujący podział terytorialny. Opracowanie kończy krótkie porównanie wynikowej koncepcji i obecnego podziału terytorialnego.
\end{abstract}

Słowa kluczowe: podział terytorialny państwa, regiony, województwa, rozwój policentryczny.

\section{Stan rzeczy. Założenia opracowania}

Następujące w ostatnich dziesięcioleciach zmiany ustroju terytorialnego świadczą o trwałości sporu o strukturę przestrzenną Polski. Również ostatnia reforma z roku 1999 nie spełniła pokładanych w niej oczekiwań. „Liczba i kształt nowych jednostek terytorialnych jest efektem zderzenia racjonalnych przesłanek, przetargów politycznych, nacisku lokalnych społeczności i grup" - stwierdza A. Nelicki (2001, s. 69). Zdanie to podziela wielu badaczy (Kowalczyk, 2000; Wendt, 2001; Miszczuk, 2003; Piotrowski, 2004; Bober i inni, 2013; Zaborowski, 2013). A. Miszczuk (2003) zwraca uwagę, że obecny układ województw odbiega od wszystkich koncepcji przedstawionych przez środowisko naukowe. W okresie 2014-2015 dyskusja nad celowością i kierunkami korekty podziału terytorialnego ponownie ożyła. Inicjatywę podejmują zarówno kręgi eksperckie (Habuda i Habuda, 2014; Honka, 2014; Sokołowski, 2014; Zaborowski, 2014; Śleszyński, 
2015), jak i strona społeczna (Bielsko-Biała, Częstochowa, Koszalin, Radom, Tarnów). Sprawdzają się ostrzeżenia, że uznaniowy dobór miast wojewódzkich będzie budzić niezadowolenie (Jałowiecki, 1991, 1997; Nelicki, 2001).

Obecny układ województw jest nie do obrony ze względu na wewnętrzną niespójność. Zarówno z analiz prowadzonych ex post, jak i z przebiegu reformy wiemy, że stanowi on konstrukcję hybrydową między modelami województw dużych i średnich (Miszczuk, 2003; Zaborowski, 2013). „Dążenie do konsekwencji w kształtowaniu podziału terytorialnego państwa wymagałoby jego korekty, polegającej na nieznacznym zwiększeniu liczby województw o jednostki dorównujące pod względem określonych kryteriów województwom już istniejącym, bądź na zmniejszeniu ich liczby” (Sokołowski, 2014, s. 586). „W świetle analizy grawitacyjnej zarówno liczba, jak też granice jednostek pierwszego szczebla obecnego podziału terytorialnego nie są optymalne. Można wnioskować, że w stosunku do obecnych 16 województw bardziej zasadny byłby podział albo na 14, albo na 18-20 jednostek" (Śleszyński, 2015, s. 343).

Zmniejszenie liczby województw byłoby nawiązaniem do pierwotnych koncepcji ostatniej reformy. Rodzi się pytanie, czy nie przyczyniłoby się do dalszej koncentracji zjawisk rozwojowych. Że taka ma miejsce, panuje powszechna zgoda, niezależnie od oceny tej tendencji (Lijewski, 2003; Śleszyński, 2007; Korcelli, 2009; Sokołowski, 2011; Czyż, 2012; Heffner, 2015; Zaborowski, 2015a). Przeciwnicy centralizacji ostrzegają, że likwidacja małych województw będzie skutkować upadkiem ich obecnych stolic. Milcząco zakłada się bowiem, iż koncepcja dużych województw utrzymuje status wojewódzki tylko największych ośrodków. Opór w tym przypadku budzi perspektywa nie tyle zniesienia województwa, ile utraty rangi przez jego ośrodek. Tymczasem należy odróżnić liczbę województw od liczby ośrodków wojewódzkich. Również obecnie nie są one tożsame, zważywszy na istnienie województw mających po dwa miasta wojewódzkie.

Propozycja rozszerzenia modelu dwubiegunowego godzi postulat zniesienia zbyt małych jednostek wojewódzkich z potrzebą wzrostu policentryczności kraju (Lijewski, 1984; Sługocki, 1997; Łysoń, 1998). Jest ona zgodna z dążeniem do równowagi pod względem wyposażenia ośrodków w infrastrukturę społeczną wyższego rzędu. Zaletą rozwiązania dwubiegunowego jest również możliwość podkreślenia tożsamości historycznej mniejszych regionów, które obecnie giną w podziale scentralizowanym na poziomie województw. Przy tego rodzaju rozwiązaniach korzystne jest, kiedy oba ośrodki w województwie cechuje podobny potencjał. Dysproporcja wiąże się z niebezpieczeństwem dominacji jednego z nich, choć oczywiście i tak mniejszej niż w modelu monocentrycznym. Płynie z tego wniosek, by mniejsze ośrodki regionalne wiązać wzajemnie ze sobą, a dopiero w przypadku braku takiej możliwości - z ośrodkami metropolitalnymi. Jest to zbieżne z postulatem podniesienia znaczenia tzw. regionów międzymetropolitalnych (Heffner, 2009). 
Pytanie o liczbę województw jest wtórne w stosunku do kwestii pożądanej wielkości jednostek. Rozstrzygnięcia w tym zakresie powinny zapaść na gruncie nie geografii, lecz teorii administracji i usług publicznych. Tutaj wypada ograniczyć się do stwierdzenia, że jeśli województwa mają pełnić te same funkcje, powinny być podobnej wielkości. Istotne znaczenie ma ponadto wybór dolnego progu wielkościowego. W niniejszym opracowaniu jest to liczba około $1 \mathrm{mln}$ ludności, zgodnie z praktyką obecnego podziału, jak również propozycjami teoretycznymi (Sokołowski, 2014).

Korektę podziału terytorialnego powinna poprzedzać dyskusja nad kształtem wszystkich trzech (a może innej liczby?) jego szczebli. Jakkolwiek właściwe byłoby rozpoczęcie reformy od poziomów niższych, nie powinno to wstrzymywać prac nad układem województw. Celem opracowania jest propozycja przebudowy podziału terytorialnego na tym szczeblu oparta na wybranych prostych czynnikach, w drodze zobiektywizowanej procedury. Jej główny kierunek nawiązuje do oczekiwań przeważających w bieżącej debacie publicznej oraz deklaracji strony rządowej. W ich świetle podział powinien zostać uzupełniony o jednostki porównywalne z obecnymi województwami, a pominięte podczas ostatniej reformy.

Przedstawiona poniżej procedura przebudowy układu województw składa się z następujących etapów:

- określenie ośrodków regionalnych,

- budowa regionów: przyporządkowanie powiatów do ośrodków regionalnych,

- budowa województw: wzajemne powiązanie regionów.

Przed właściwymi czynnościami przebudowy następuje krótka dyskusja czynników budowy regionów i województw. Ze względu na ograniczony zakres artykułu w toku prac uwzględniono tylko wybrane czynniki, szczególnie te, które nie wymagają długotrwałych badań bądź konsultacji. Wynikowa mapa nie jest zatem gotowym projektem zmian, lecz teoretyczną próbą przybliżenia możliwych rozwiązań. Tezą opracowania jest, że uzyskana koncepcja - mimo prostej metodyki - w znacznym stopniu usuwa wady obecnego podziału, którymi są przede wszystkim (Zaborowski, 2013):

- nierównowaga wielkościowa województw,

- odmienne traktowanie porównywalnych ośrodków,

- przecięcie granicami województw obszarów funkcjonalnych dużych miast,

- nieadekwatne określenie tożsamości historycznej województw.

\section{Czynniki budowy regionów i województw}

Tworzenie podziału terytorialnego jest procesem złożonym. Działania na danym etapie rozpoczynają się od wyboru poziomu przestrzennego, który będzie stanowił zbiór jednostek składowych, niepodlegających zmianom. Z kolei ma miejsce wybór ośrodków - „stolic”, a następnie przyporządkowanie jednostek składowych do ośrodków według ustalonych czynników (Zaborowski, 2013). 
Podstawowym wymogiem stawianym jednostce podziału terytorialnego jest jej spójność przestrzenna (Kaczmarek, 2005). W praktyce znaczenie ma tu nie tyle kształt granic, ile spójność komunikacyjna (Liszewski, 1991; Łysoń, 1998). Podnoszone jest ogólne żądanie współzależności podziału terytorialnego i struktury zagospodarowania kraju (Wróbel, 1984; Kołodziejski, 1991; Zioło, 1992), w tym zwłaszcza sieci osadniczej (Kołodziejski i Stasiak, 1986; Wróbel, 1986; Heffner i Rochmińska, 2000). Wynikiem powinno być zachowanie całości regionów węzłowych (Kołodziejski i Stasiak, 1986; Szczepkowski, 1991; Chojnicki i Czyż, 2000). Z drugiej strony wymaga się uwzględnienia związków historyczno-kulturowych (Piskozub, 1987; Czyżewska i Kostarczyk, 1989; Liszewski, 1991; Szczepkowski, 1991; Łysoń, 1998; Heffner i Rochmińska, 2000). Szczególnym czynnikiem jest tutaj tożsamość etniczna ludności (Kołodziejski, 1991; Szczepkowski, 1991; Chojnicki i Czyż, 2000). Wyrazem więzi kulturowych mogą być także podziały terytorialne podmiotów niepaństwowych. W przypadku Polski dotyczy to zwłaszcza Kościoła katolickiego (Jałowiecki, 1991; Heffner i Rochmińska, 2000).

Te dwie grupy czynników mogą dawać sprzeczne przesłanki do wyodrębniania regionów. Dodatkowe wątpliwości budzi pytanie, czy powyższe cechy regionów są stałe, czy zmienne w czasie. A jeśli zmienne, to czy są - i w jakim stopniu - współzależne? Co za tym idzie: na ile poszczególne cechy konstytuujące regiony powinny być czynnikami tworzenia podziału, a na ile są skutkiem jego istnienia? Obecny układ granic województw ma istotny wpływ na więzi społeczno-gospodarcze (Chojnicki i Czyż, 1992). Lokalizacja instytucji sfery publicznej wymusza kontakty z ośrodkiem administracji. Kształt jednostki wpływa też wtórnie na dostępność komunikacyjną, przede wszystkim dlatego, że samorząd wojewódzki jest organizatorem transportu publicznego. Ponadto podmioty prywatne często dostosowują swoją strukturę terytorialną do podziału publicznego. Jeśli zatem obecne więzi społeczno-gospodarcze są w dużym stopniu pochodną obowiązującego ustroju terytorialnego, to branie ich za główną przyczynę nowych rozstrzygnięć zakrawa na błąd logiczny. „Do reformy potrzeba idei, której źródła nie można znaleźć wśród stosunków mających być właśnie zreformowanymi" - zauważa przed stu laty Władysław Leopold Jaworski, znawca prawa ustrojowego (Piskozub, 1987, s. 178). Przydanie zbyt dużej wagi związkom funkcjonalnym byłoby niemiarodajne zwłaszcza przy rozgraniczaniu regionów między obecnym miastem wojewódzkim a ośrodkiem, który taką funkcję dopiero ma zacząć pełnić. Oczywiście nie oznacza to, jakoby omawiany czynnik należało pomijać. Jakkolwiek podział terytorialny jest bardzo silnym narzędziem planistycznym, związki funkcjonalne nie mogą być kształtowane zupełnie dowolnie. Próbę ich diametralnego odwrócenia trudno byłoby uznać za celową bądź racjonalną. Dopuścić zaś należy ewolucyjną zmianę istniejących zależności. 
A zatem oprócz pytania: gdzie występują związki funkcjonalne? należy także rozważyć: który spośród wariantów podziału będzie prowadzić do tworzenia optymalnych związków, optymalnego wykorzystania przestrzeni? Skąd wywodzić tę optymalność? Wyjdźmy od tego, że ośrodki regionalne są miejscem kształtowania infrastruktury społecznej wyższego rzędu, służącej przyległemu obszarowi. Jeśli każdy ośrodek będzie zaspokajał możliwie szeroki zakres potrzeb, dostęp do najbliższego z nich minimalizuje konieczność przemieszczeń w obrębie układu. W tym świetle podstawowym czynnikiem rozgraniczenia regionów byłaby dostępność ośrodków. Miarą tejże może być odległość bądź czas dojazdu. Ten drugi parametr w krótkim okresie lepiej oddaje rzeczywistą dostępność, jednak w dłuższej perspektywie - wobec poprawy jakości infrastruktury - może się znacząco zmieniać, w przeciwieństwie do odległości. Ponadto czas będzie różny dla transportu publicznego i indywidualnego. W przypadku komunikacji publicznej, którą należałoby traktować priorytetowo, miarą dostępności jest także częstość połączeń. A jak zauważono przed chwilą, system transportu publicznego zależy od obecnego podziału terytorialnego. Dlatego w niniejszym opracowaniu za miarę dostępności przyjęto odległość po sieci komunikacyjnej.

Ani współczesne więzi społeczno-gospodarcze, ani dostępność nie muszą oznaczać wspólnoty kulturowej. Wobec podejmowanych w Polsce „ludowej” prób zatarcia różnorodności kulturowej kraju, jako pożądana jawi się odnowa tych wartości przy udziale samorządów wojewódzkich. Oczywiste jest, że będzie to bardziej skuteczne w jednostkach o możliwie jednorodnej tożsamości. Tu nasuwa się pytanie, co z ośrodkami, które powstały na granicach regionów historycznych. Klasycznym przykładem jest Bielsko-Biała. Takie miasta też tworzą regiony węzłowe, których podział wzdłuż dawnych granic byłby nieracjonalny w świetle argumentów przedstawionych wyżej. Nieuniknione jest zatem dopuszczenie modelu regionu o podwójnej tożsamości. Rozwiązanie takie jest do przyjęcia po warunkiem, że oba człony mają równy status w polityce ochrony dziedzictwa kulturowego. Za niekorzystną należy natomiast uznać przynależność niewielkich, krańcowych terytoriów do większych jednostek o odmiennej tradycji kulturowej. Obszary takie, pozbawione infrastruktury kulturalnej wyższego rzędu, byłyby narażone na utratę tożsamości.

Podsumowując: województwo ma być regionem węzłowym bądź zespołem regionów węzłowych. Wyodrębniane uprzednio regiony będą się cechować możliwie jednorodną - względnie podwójną, ale jednoznacznie określoną - tożsamością historyczną. Kryterium węzłowości stanowi bliskość ośrodka regionalnego, maksymalizująca dostęp do dóbr publicznych oraz sprzyjająca kształtowaniu więzi społeczno-gospodarczych. Z tych dwóch czynników: o ile odległość jest kryterium stosunkowo prostym, o tyle tożsamość historyczna wymaga wstępnych założeń co do struktury kraju. 


\section{Założenia co do struktury historycznej kraju}

Niniejsze wyróżnienie krain historycznych Polski należy traktować jako założenie niezbędne do dalszej części wywodu. Jest ono oparte na dostępnych źródłach, a nie na wynikach badań własnych. Przez „krainy historyczne” rozumie się duże jednostki terytorialne - wielkości dzielnic, prowincji - posiadające odrębność prawno-polityczną w którymś z dwóch głównych okresów stabilności ustroju terytorialnego ziem polskich. Pierwszy z nich to czasy Pierwszej Rzeczpospolitej - państwa o przemożnym znaczeniu kulturowym nie tylko dla narodu polskiego, ale i dla innych narodów Europy Środkowo-Wschodniej. Warto zwrócić uwagę na wyjątkową trwałość struktury terytorialnej Rzeczpospolitej (Kostarczyk, 1997). Jakkolwiek w późniejszych okresach staropolskie podziały terytorialne zanikały w świadomości społecznej, mimo to (a może właśnie: dlatego) uwzględnienie tej istotnej warstwy dziedzictwa narodowego wydaje się celowe. Drugi okres trwałości granic politycznych ma zgoła inny charakter, bo związany jest z czasem podziału ziem polskich między obce byty państwowe. Kordony zaborcze istotnie wpłynęły na tożsamość terytorialną i do dzisiaj widoczne są w zjawiskach społecznych oraz strukturze przestrzeni (Plit, 2015). W kontekście zmienności granic państwa polskiego, jak również długotrwałego oderwania niektórych prowincji od macierzy, w poniższej klasyfikacji przyjęto zasadę przywracania polskiej tradycji terytorialnej. Mianowicie obszary pograniczne o zmiennej przynależności kojarzono z dzielnicami, których historyczny związek z państwem polskim jest większy. Ponadto należy rozważyć przypadek terytoriów stanowiących dziedzictwo historyczne państw sąsiednich, z których jedynie niewielkie krańce należą obecnie do Polski. Tego rodzaju regiony kresowe będą rozpatrywane wspólnie z większymi jednostkami, do których przylegają.

Na dawnych ziemiach Rzeczpospolitej wyróżniono następujące krainy historyczne (Gloger, 1903; Piskozub, 1987; Wysocka i Konopka, 1997):

- Wielkopolska, w tym Kujawy z ziemią dobrzyńską oraz województwa łęczyckie i sieradzkie,

- Mazowsze,

- Prusy Królewskie, w tym okręgi Bytowa i Lęborka; bez Warmii,

- Warmia,

- Prusy Książęce,

- Małopolska, w tym Ruś Czerwona, wraz z krańcami Orawy i Spisza,

- Podlasie wraz z krańcami Wielkiego Księstwa Litewskiego.

Okręgi Bytowa i Lęborka zostały zaliczone do Pomorza Gdańskiego zgodnie z zasadą przywracania polskiej tożsamości terytorialnej. Warmię wyróżniono jako odrębną krainę ze względu nie tylko na jej szczególny status, ale i odrębność terytorialną: była prawie enklawą wewnątrz Prus Książęcych (Gloger, 1903; Plit, 2015). Prowincja małopolska, w odróżnieniu od Małopolski sensu stricto, 
obejmowała także koronne ziemie ruskie, dlatego terytoria te uwzględnione są wspólnie. Oddzielnie potraktowano województwo podlaskie, które po przyłączeniu do Korony także było zaliczane do prowincji małopolskiej. Podlasie odróżnia jednak uprzednia przynależność do Wielkiego Księstwa Litewskiego. Cechuje je ponadto znaczna odrębność przestrzenna od reszty prowincji. Wraz z Podlasiem uwzględniono fragmenty Wielkiego Księstwa Litewskiego, które znajdują się w obecnych granicach państwa polskiego. Uzasadnieniem jest analogiczna przeszłość - ziem litewsko-ruskich przyłączonych do Korony (Gloger, 1903; Piskozub, 1987; Wysocka i Konopka, 1997).

Szczególne podejście konieczne jest w stosunku do tzw. ziem zachodnich. Nie wchodziły one w skład Rzeczpospolitej, ponadto powojenna wymiana ludności istotnie naruszyła ich ciągłość kulturową. Główne dzielnice ziem zachodnich to Śląsk i Pomorze Zachodnie. Pomiędzy nimi znajduje się stosunkowo niewielki obszar, w średniowieczu stanowiący (w części) ziemię lubuską, następnie brandenburską Nową Marchię. Nową Marchię, jako powstałą pierwotnie z ziem pomorskich (Czarnuch, 2004), rozpatruje się wspólnie z Pomorzem Zachodnim. Jednocześnie granice Śląska potraktowano maksymalnie szeroko, zgodnie z zasadą przywracania polskiej tradycji terytorialnej.

Nałożenie podziałów z obu okresów daje mapę krain historycznych Polski (ryc. 1). Dwie główne prowincje Korony: Wielkopolska i Małopolska - zostają wtórnie przecięte granicami XIX-wiecznymi. Umowne nazwy powstających w ten sposób krain utworzono od kierunków geograficznych: Małopolska „północna” i Wielkopolska „wschodnia” - to części należące do „kongresowego” Królestwa Polskiego; odpowiednio połowy „południowa” i „zachodnia” wchodziły w skład zaborów austriackiego i pruskiego. Wtórna granica dzieli także Śląsk, gdzie wyróżniono habsburski Śląsk Cieszyński oraz główną - „pruską” - część dzielnicy, pozostawiając jej nazwę bez dodatkowego przymiotnika. Należy ponadto zwrócić uwagę, że przebieg odpowiadających sobie granic z poszczególnych okresów nie musi ściśle się pokrywać. Jednakże na poziomie szczegółowości przyjętym w niniejszym opracowaniu - czyli przynależności miast powiatowych - nałożenie granic pozostaje jednoznaczne.

W kwestii kulturowej uwzględniono także obszary ze znacznym udziałem ludności o odmiennej tożsamości etnicznej. Jako „społeczność etniczna” rozumiana jest zarówno mniejszość narodowa, jak i inna grupa regionalna, do której przynależność deklarowano w Narodowym Spisie Powszechnym z roku 2011. Poszczególne społeczności etniczne przypisano do regionów historycznych. Pominięto natomiast obszary, gdzie dana społeczność została rozproszona w wyniku powojennych przesiedleń. Powiat ziemski uznano umownie za zamieszkany przez daną społeczność etniczną, jeśli odsetek deklarujących przynależność do niej przekraczał 1000 osób lub 2\% ogółu ludności. Wybór tak niskiego progu jest celowy - zmierza do ochrony tożsamości również w krańcowych powiatach obszaru zamieszkanego przez daną społeczność. 


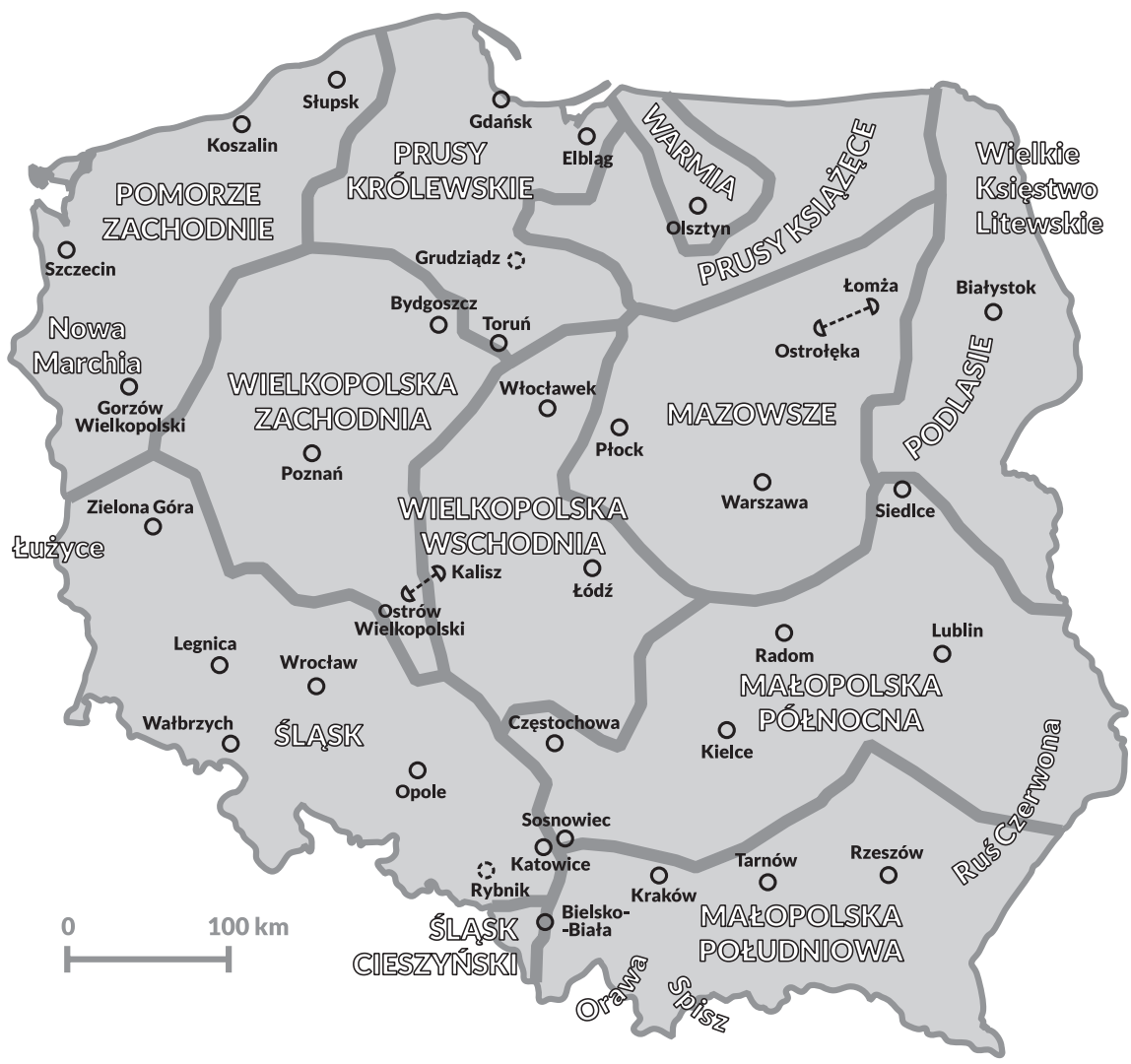

Ryc. 1. Uproszczony podział Polski na krainy historyczne

Simplified division of Poland into historical provinces Opracowanie własne na podstawie / Author's elaboration based on:

Piskozub (1987); Kostarczyk (1997); Zaborowski (2013).

\section{Zestawienie ośrodków regionalnych}

Listę ośrodków regionalnych przyjęto jako daną - w nawiązaniu do opracowania Ł. Zaborowskiego (2014). Czynnikami klasyfikacji była liczba ludności: w samym ośrodku (gmina miejska albo potencjalny miejski obszar funkcjonalny) oraz w jego regionie węzłowym (obszar bliższy danemu ośrodkowi niźli ośrodkom sąsiednim). Ośrodki stanowione są w większości przez pojedyncze miasta, w nielicznych przypadkach - przez zespoły miast. Zespół taki może być konurbacją w rozumieniu teorii osadnictwa bądź parą miast, która ma wspólnie pełnić funkcje jednego ośrodka na mocy ustalenia planistycznego. 
Ośrodki podzielono na kategorie wielkościowe. W ośrodkach metropolitalnych - zgodnie z Koncepcja Przestrzennego Zagospodarowania Kraju 2030 - centralna gmina miejska ma więcej niż 300 tys. ludności. Wyróżniono dwa ośrodki metropolitalne „większe” (M+), które od pozostałych (M) dzieli różnica kilkuset tysięcy mieszkańców - i dla ośrodka, i dla regionu. Ośrodki regionalne sensu stricto (R) to samodzielne - położone poza aglomeracjami - miasta, które przekroczyły próg 100 tys. mieszkańców, uznawany za graniczny dla miast dużych. Z uwagi na obecny ubytek ludności w miastach można przyjąć, że próg ten wynosi 90 tys. ludności. Do tej stawki dołączono dwa ośrodki mniejsze, ale o porównywalnych regionach, położone w obszarach najbardziej oddalonych od innych ośrodków.

Cztery ośrodki regionalne ze względu na położenie w bliskości innych ośrodków zakwalifikowano jako niesamodzielne - obligatoryjnie powiązane z ośrodkami sąsiednimi. Ma to znaczenie tylko proceduralne - nie zmierza do pozbawienia ich statusu ośrodków regionalnych, a tym samym predyspozycji do pełnienia funkcji wojewódzkich. Elbląg, Grudziądz i Rybnik są jednoznacznie przypisane do pobliskich ośrodków metropolitalnych. Czwarty z ośrodków o takiej charakterystyce - Włocławek - jest rozpatrywany oddzielnie, ponieważ może być wiązany alternatywnie z ośrodkami położonymi w różnych kierunkach.

W zestawieniu ośrodków (tab. 1) określono tożsamość historyczną ich regionów. Jak ustalono wyżej, ośrodki na pograniczach krain historycznych mają regiony o tożsamości złożonej. W przypadku ośrodków stanowionych przez zespoły większej liczby miast, dla uproszczenia w nazwach wymieniane będą dwa wybrane jako główne. Podobnie nazwy krain historycznych ograniczono do członu głównego. Do ośrodków przypisano także społeczności etniczne, przy czym w tabeli pominięto obszary obejmujące tylko jeden powiat. Ich przyporządkowanie do dowolnego regionu nie niesie ryzyka przedzielenia granica, a zatem nie ma znaczenia dla poniższej procedury.

\section{Budowa regionów}

Budowa regionów odbywała się przez przyporządkowanie ośrodków powiatowych do regionalnych. Obecne granice powiatów przyjęto jako dane; przyporządkowanie ośrodka jest równoznaczne z przyporządkowaniem całego powiatu. Jako pierwszy stosowano czynnik podstawowy, a mianowicie:

- przyporządkowanie ośrodka powiatowego do najbliższego ośrodka regionalnego pod warunkiem przynależności do tej samej krainy historycznej.

W przypadkach nierozstrzygniętych stosowano czynniki posiłkowe:

- ochrona tożsamości pojedynczych powiatów (T),

- związki na poziomie okręgowym (podregionalnym) (O),

- inne związki na poziomie regionalnym (I). 
Tabela 1. Ośrodki regionalne według kategorii wielkościowej i tożsamości historycznej Regional centres by size category and historical identity

\begin{tabular}{|c|c|c|c|}
\hline $\begin{array}{l}\text { Ośrodek regionalny } \\
\text { Regional center }\end{array}$ & $\begin{array}{c}\text { Kategoria } \\
\text { wielkościowa } \\
\text { Size } \\
\text { category }\end{array}$ & $\begin{array}{l}\text { Kraina historyczna } \\
\text { Historical province }\end{array}$ & $\begin{array}{c}\text { Społeczność } \\
\text { etniczna } \\
\text { w regionie } \\
\text { Ethnic commu- } \\
\text { nity in region }\end{array}$ \\
\hline Białystok & $\mathrm{R}$ & Podlasie & Białorusini \\
\hline Bielsko-Biała & $\mathrm{R}$ & Małopolska południowa / Śląsk Cieszyński & Ślązacy \\
\hline Bydgoszcz-Toruń & M & $\begin{array}{l}\text { Prusy Królewskie / Wielkopolska zachod- } \\
\text { nia }\end{array}$ & \\
\hline Częstochowa & $\mathrm{R}$ & $\begin{array}{l}\text { Małopolska północna / Wielkopolska } \\
\text { wschodnia }\end{array}$ & \\
\hline Elbląg-Gdańsk & M & Prusy Królewskie & Kaszubi \\
\hline Gorzów Wlkp. & $\mathrm{R}$ & Pomorze Zachodnie (Nowa Marchia) & \\
\hline Kalisz-Ostrów Wlkp. & $\mathrm{R}$ & Wielkopolska wschodnia/zachodnia & \\
\hline Katowice-Sosnowiec & $\mathrm{M}+$ & Małopolska południowa/północna / Śląsk & Niemcy, Ślązacy \\
\hline Kielce & $\mathrm{R}$ & Małopolska północna & \\
\hline Koszalin & $\mathrm{R}$ & Pomorze Zachodnie & \\
\hline Kraków & M & Małopolska południowa/północna & \\
\hline Legnica & $\mathrm{R}$ & 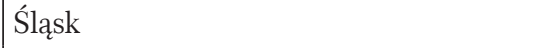 & \\
\hline Lublin & M & Małopolska północna & \\
\hline Łomża-Ostrołęka & $\mathrm{R}$ & Mazowsze & \\
\hline Łódź & M & Wielkopolska wschodnia & \\
\hline Olsztyn & $\mathrm{R}$ & Prusy Książęce / Warmia & \\
\hline Opole & $\mathrm{R}$ & Śląsk & Niemcy, Ślązacy \\
\hline Płock & $\mathrm{R}$ & Mazowsze & \\
\hline Poznań & M & Wielkopolska zachodnia & \\
\hline Radom & $\mathrm{R}$ & Małopolska północna & \\
\hline Rzeszów & $\mathrm{R}$ & Małopolska południowa & \\
\hline Siedlce & $\mathrm{R}$ & Małopolska północna / Podlasie & \\
\hline Słupsk & $\mathrm{R}$ & Pomorze Zachodnie & \\
\hline Szczecin & M & Pomorze Zachodnie & \\
\hline Tarnów & $\mathrm{R}$ & Małopolska południowa & \\
\hline Wałbrzych & $\mathrm{R}$ & Śląsk & \\
\hline Warszawa & $\mathrm{M}+$ & Mazowsze & \\
\hline Włocławek & $\mathrm{R}$ & Wielkopolska wschodnia & \\
\hline Wrocław & M & 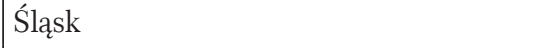 & \\
\hline Zielona Góra & $\mathrm{R}$ & Śląsk & \\
\hline
\end{tabular}

Opracowanie własne na podstawie / Author's elaboration based on: Narodowy Spis... (2011); Zaborowski (2013, 2014). 
Ponadto przyjęto następujące ograniczenia dopuszczalnych przyporządkowań:

- zachowanie zwartości terytorialnej jednostki (Z),

- przypisanie społeczności etnicznej do jej regionu historycznego (E),

- ograniczenie wielkości regionów ośrodków metropolitalnych większych (W).

Zgodnie z czynnikiem podstawowym ośrodek powiatowy zostaje przyporządkowany do najbliższego ośrodka regionalnego, jeśli oba należą do tej samej krainy historycznej. Odległość liczono po trasie drogowej, a ponadto kolejowej, o ile ta była dostępna w danej relacji. Jeśli dla danego ośrodka powiatowego dostępne są obie gałęzi transportu, rozstrzygające było porównanie połączeń kolejowych. Ośrodek powiatowy zostawał przyporządkowany do danego ośrodka regionalnego, jeśli odległość do niego jest mniejsza niż porównywalna z odległością do innych ośrodków. Za odległość porównywalną uznano umownie dystans do 30\% dłuższy niż do ośrodka najbliższego. To dość wysokie odchylenie przyjęto celowo: zwiększa liczbę przypadków pogranicznych, które były rozpatrywane dodatkowo w świetle czynników posiłkowych.

Czynniki posiłkowe stosowano kolejno: jeśli pierwszy był rozstrzygający, nie rozważano następnych. Zasada ochrony tożsamości pojedynczych powiatów nie dopuszcza przyporządkowania odosobnionego powiatu do regionu o innej tożsamości historycznej. Zostaje on przyporządkowany zgodnie ze swoją tożsamością, zatem niekoniecznie do najbliższego ośrodka regionalnego. Zasadę tę stosowano, jeśli granica historyczna, przy której leży rozpatrywany powiat, przetrwała w późniejszych podziałach na poziomie regionalnym. Przez związki na poziomie okręgowym rozumie się położenie w zasięgu potencjalnego funkcjonalnego obszaru miejskiego (Zaborowski, 2014), w obszarze metropolitalnym (według planu zagospodarowania przestrzennego województwa) bądź przynależność do okręgu przemysłowego. Z kolei inne związki na poziomie regionalnym są następstwem podziałów terytorialnych historycznych i współczesnych. Uwzględniano trzy kategorie: regiony administracyjne z lat 1816-1999, obecne województwa i diecezje Kościoła katolickiego.

Jeśli chodzi o ograniczenia dopuszczalnych przyporządkowań, stanowiły one powód wstrzymania przyporządkowania, które wynikałoby z czynników przedstawionych przed chwilą. Zwartość terytorialną należy rozumieć jako możliwe zbliżenie kształtu powstającej jednostki do koła. W toku prac uznano ją za ograniczenie w nielicznych przypadkach, które nie wydają się dyskusyjne - dlatego odstąpiono od ścisłego definiowania tego pojęcia. Zwartość traktowano jako warunek bezwzględny, natomiast dwa kolejne ograniczenia jedynie wstrzymywały rozstrzygnięcie do etapu budowy województw. W przypadku zamieszkiwania powiatu przez wyróżnioną społeczność etniczną nie dopuszczano przyporządkowania do ośrodka regionalnego innego niż wskazany dla danej społeczności. Wreszcie co do ograniczenia wielkości regionów większych ośrodków metropolitalnych: przyjęto, że w skład takiego regionu wchodzą tylko powiaty, których 
ośrodki są zaliczane do odpowiedniego obszaru metropolitalnego według planu zagospodarowania przestrzennego województwa.

Wynikiem etapu budowy regionów są jednostki składowe do budowy województw (ryc. 2): regiony (tab. 2) oraz pogranicza (tab. 3). Te ostatnie to powiaty, których nie dało się jednoznacznie przyporządkować na podstawie przyjętych czynników. W tabelach skrótami zaznaczono przypadki przyporządkowania według czynników posiłkowych (bądź ograniczeń). W innych przypadkach rozstrzygający był czynnik podstawowy.

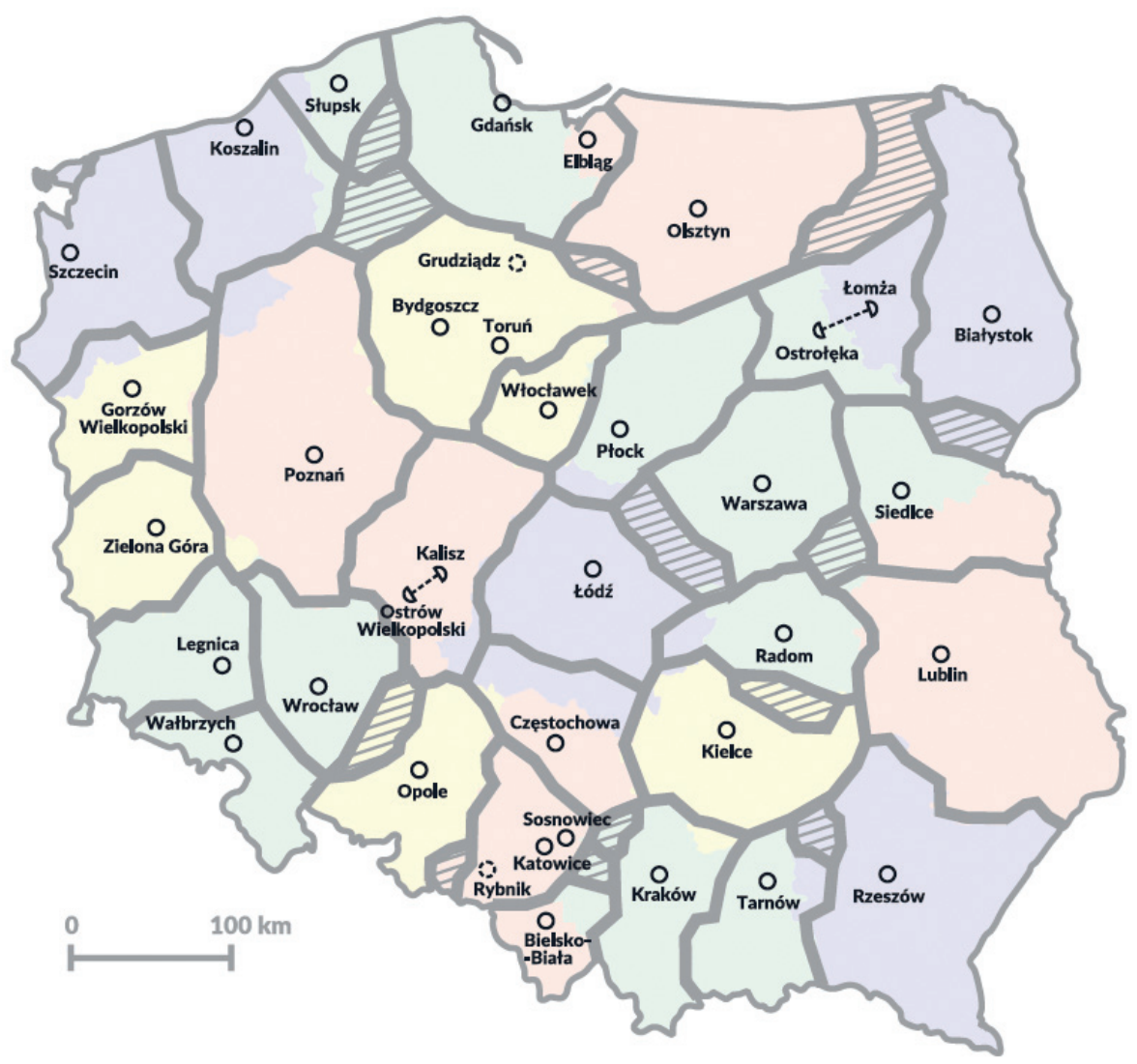

Ryc. 2. Regiony i pogranicza - jednostki składowe do budowy województw.

W tle obecny układ województw (oznaczony kolorami)

Regions and border areas - components in the building of voivodships.

The present system of voivodships is presented in the background (coloured)

Opracowanie własne / Author's own elaboration. 
Tabela 2. Regiony jako wynik przyporządkowania powiatów do ośrodków regionalnych

Regions arising as county-level units (poviats) are attached to regional centres

\begin{tabular}{|c|c|c|}
\hline $\begin{array}{l}\text { Ośrodek } \\
\text { regionalny } \\
\text { Regional } \\
\text { center }\end{array}$ & $\begin{array}{c}\text { Ośrodki powiatowe } \\
\text { County (poviat) centers (auxiliary factor) }\end{array}$ & $\begin{array}{c}\text { Ludność } \\
\text { (tys.) } \\
\text { Popu- } \\
\text { lation } \\
\text { ('000) }\end{array}$ \\
\hline Białystok & $\begin{array}{l}\text { Augustów, Bielsk Podlaski, Hajnówka, Mońki, Sejny, Sokółka, Suwałki, } \\
\text { Wysokie Mazowieckie }\end{array}$ & 900 \\
\hline Bielsko-Biała & Cieszyn, Oświęcim, Wadowice, Żywiec & 980 \\
\hline \begin{tabular}{l|l} 
Bydgoszcz- & \\
Toruń
\end{tabular} & $\begin{array}{l}\text { Brodnica, Chełmno, Golub-Dobrzyń, Grudziądz, Inowrocław, Mogilno } \\
\text { (I), Nakło, Sępólno Krajeńskie, Świecko, Tuchola, Wąbrzeźno, Żnin }\end{array}$ & 1680 \\
\hline Częstochowa & Kłobuck, Myszków (I), Pajęczno, Radomsko, Wieluń, Zawiercie (O, I) & 890 \\
\hline \begin{tabular}{l|l} 
Elbląg-- & \\
Gdańsk
\end{tabular} & $\begin{array}{l}\text { Kartuzy, Kościerzyna, Kwidzyn (T, I), Lębork, Malbork, Nowy Dwór } \\
\text { Gdański, Puck, Starogard Gdański, Sztum, Tczew, Wejherowo }\end{array}$ & 2060 \\
\hline $\begin{array}{l}\text { Gorzów } \\
\text { Wlkp. }\end{array}$ & $\begin{array}{l}\text { Międzyrzecz (I), Myślibórz, Słubice, Strzelce Krajeńskie-Drezdenko, } \\
\text { Sulęcin }\end{array}$ & 455 \\
\hline $\begin{array}{l}\text { Kalisz- } \\
\text { Ostrów Wlkp. }\end{array}$ & $\begin{array}{l}\text { Jarocin (I), Kępno, Koło, Konin, Krotoszyn, Ostrzeszów, Pleszew, Słup- } \\
\text { ca (T), Turek, Wieruszów }\end{array}$ & 1155 \\
\hline \begin{tabular}{l|l} 
Katowice- \\
Sosnowiec
\end{tabular} & $\begin{array}{l}\text { Bieruń-Lędziny, Lubliniec (T, Z), Mikołów, Pszczyna (T), Rybnik, Tar- } \\
\text { nowskie Góry, Wodzisław Śląski }\end{array}$ & 3165 \\
\hline Kielce & $\begin{array}{l}\text { Busko Zdrój, Jędrzejów, Końskie, Opatów, Pińczów, Sandomierz (T, Z), } \\
\text { Staszów, Włoszczowa }\end{array}$ & 945 \\
\hline Koszalin & Białogard, Drawsko Pomorskie (I), Kołobrzeg, Szczecinek, Świdwin & 490 \\
\hline Kraków & $\begin{array}{l}\text { Bochnia (O), Kazimierza Wielka, Miechów, Myślenice, Nowy Targ, } \\
\text { Proszowice, Sucha Beskidzka (I), Wieliczka, Zakopane }\end{array}$ & 1850 \\
\hline Legnica & $\begin{array}{l}\text { Bolesławiec, Głogów (O), Jawor, Lubań, Lubin, Lwówek Śląski, Polko- } \\
\text { wice, Zgorzelec, Złotoryja }\end{array}$ & 800 \\
\hline Lublin & $\begin{array}{l}\text { Biłgoraj, Chełm, Hrubieszów, Janów Lubelski, Krasnystaw, Kraśnik, } \\
\text { Lubartów, Łęczna, Opole Lubelskie, Parczew, Puławy, Ryki (O), Świd- } \\
\text { nik, Tomaszów Lubelski, Włodawa (Z), Zamość }\end{array}$ & 1810 \\
\hline $\begin{array}{l}\text { Łomża- } \\
\text { Ostrołęka }\end{array}$ & $\begin{array}{l}\text { Grajewo (T), Kolno, Maków Mazowiecki (I), Ostrów Mazowiecka, } \\
\text { Zambrów }\end{array}$ & 510 \\
\hline Łódź & $\begin{array}{l}\text { Bełchatów, Brzeziny, Łask, Łęczyca, Pabianice, Piotrków Trybunalski, } \\
\text { Poddębice, Sieradz (O), Tomaszów Maz., Zduńska Wola, Zgierz }\end{array}$ & 1825 \\
\hline Olsztyn & $\begin{array}{l}\text { Bartoszyce, Braniewo (T), Działdowo, Giżycko, Iława, Kętrzyn, Lidz- } \\
\text { bark Warmiński, Mrągowo, Nidzica, Ostróda, Szczytno, Węgorzewo }\end{array}$ & 1010 \\
\hline Opole & $\begin{array}{l}\text { Głubczyce (I), Kędzierzyn-Koźle (I), Kluczbork, Krapkowice, Nysa, } \\
\text { Olesno, Prudnik, Strzelce Opolskie (I) }\end{array}$ & 865 \\
\hline Płock & $\begin{array}{l}\text { Ciechanów (Z), Gostynin, Kutno, Mława (O, Z), Płońsk (I), Przasnysz } \\
(\mathrm{O}, \mathrm{Z}) \text {, Sierpc, Żuromin }\end{array}$ & 780 \\
\hline
\end{tabular}




\begin{tabular}{|c|c|c|}
\hline $\begin{array}{l}\text { Ośrodek } \\
\text { regionalny } \\
\text { Regional } \\
\text { center }\end{array}$ & $\begin{array}{c}\text { Ośrodki powiatowe } \\
\text { County (poviat) centers (auxiliary factor) }\end{array}$ & $\begin{array}{l}\text { Ludność } \\
\text { (tys.) } \\
\text { Popu- } \\
\text { lation } \\
\text { ('000) }\end{array}$ \\
\hline Poznań & $\begin{array}{l}\text { Chodzież, Czarnków-Trzcianka (I), Gniezno, Gostyń, Grodzisk Wielko- } \\
\text { polski, Kościan, Leszno, Międzychód, Nowy Tomyśl, Oborniki, Piła (I), } \\
\text { Rawicz (T), Szamotuły, Środa Wielkopolska, Śrem, Wałcz (O), Wągro- } \\
\text { wiec, Wolsztyn, Września, Wschowa (O), Złotów (O) }\end{array}$ & 2455 \\
\hline Radom & $\begin{array}{l}\text { Białobrzegi (I), Kozienice, Lipsko, Opoczno (T, I), Przysucha, Szydło- } \\
\text { wiec, Zwoleń }\end{array}$ & 695 \\
\hline Rzeszów & $\begin{array}{l}\text { Brzozów, Jarosław, Jasło, Kolbuszowa, Krosno, Lesko, Leżajsk, Luba- } \\
\text { czów, Łańcut, Nisko, Przemyśl, Przeworsk, Ropczyce-Sędziszów, } \\
\text { Sanok, Stalowa Wola, Strzyźów, Tarnobrzeg, Ustrzyki Dolne }\end{array}$ & 1860 \\
\hline Siedlce & $\begin{array}{l}\text { Biała Podlaska, Łosice, Łuków, Radzyń Podlaski (I), Sokołów Podlaski, } \\
\text { Węgrów }\end{array}$ & 655 \\
\hline Słupsk & Sławno & 250 \\
\hline Szczecin & $\begin{array}{l}\text { Choszczno, Goleniów, Gryfice (I), Gryfino, Kamień Pomorski, Łobez } \\
\text { (I), Police, Pyrzyce, Stargard, Swinoujście }\end{array}$ & 1050 \\
\hline Tarnów & $\begin{array}{l}\text { Brzesko, Dąbrowa Tarnowska, Dębica (I), Gorlice, Limanowa (O), } \\
\text { Nowy Sącz }\end{array}$ & 1135 \\
\hline Wałbrzych & $\begin{array}{l}\text { Dzierżoniów, Jelenia Góra, Kamienna Góra, Kłodzko, Świdnica, Ząbko- } \\
\text { wice Śląskie (I) }\end{array}$ & 860 \\
\hline Warszawa & $\begin{array}{l}\text { Grodzisk Mazowiecki, Grójec, Legionowo, Mińsk Mazowiecki, Nowy } \\
\text { Dwór Mazowiecki, Otwock, Piaseczno, Pruszków, Pułtusk, Sochaczew, } \\
\text { Wołomin, Wyszków, Żyrardów }\end{array}$ & 3355 \\
\hline Włocławek & Aleksandrów Kujawski (T), Lipno, Radziejów, Rypin & 410 \\
\hline Wrocław & $\begin{array}{l}\text { Góra (I), Milicz, Oleśnica, Oława, Strzelin, Środa Śląska (I), Trzebni- } \\
\text { ca, Wołów (I) }\end{array}$ & 1250 \\
\hline Zielona Góra & Krosno Odrzańskie, Nowa Sól, Świebodzin, Żagań, Żary & 595 \\
\hline
\end{tabular}

Opracowanie własne na podstawie / Author’s elaboration based on: Zaborowski (2013).

Powiaty grodzkie w konurbacjach pominięto. / Urban counties in conurbations are omitted.

Dla uproszczenia jako nazwa regionu, względnie pogranicza, została przyjęta nazwa ośrodka. Jak wspomniano wyżej, za punkt wyjścia do budowy regionów przyjęto obecny układ powiatów. Zważywszy jednak, że również poziomy lokalne podziału terytorialnego wymagają przebudowy, uzyskane tutaj granice regionów i województw należy traktować jako przybliżone. Dlatego na mapach zaznaczono je grubymi liniami. W przypadku rzeczywistej reformy mogłyby ulec modyfikacjom zależnie od rozstrzygnięć na niższych szczeblach. 
Tabela 3. Pogranicza - możliwe przyporządkowanie

Border areas - possible attachment

\begin{tabular}{|c|c|c|c|c|}
\hline \multirow{2}{*}{$\begin{array}{l}\text { Pogranicze } \\
\text { Ośrodki powiatowe } \\
\text { Border areas } \\
\text { County-level centers }\end{array}$} & \multirow{2}{*}{$\begin{array}{l}\text { Ludność } \\
\text { (tys.) } \\
\text { Population } \\
\text { ('000) }\end{array}$} & \multirow{2}{*}{$\begin{array}{l}\text { Kraina histo- } \\
\text { ryczna } \\
\text { Społeczność } \\
\text { etniczna } \\
\text { Historical } \\
\text { province } \\
\text { Ethnic } \\
\text { community }\end{array}$} & \multicolumn{2}{|c|}{$\begin{array}{l}\text { Możliwe przyporządkowanie do ośrod- } \\
\text { ków regionalnych według czynników } \\
\text { Possible attachment to regional centers } \\
\text { in line with factors }\end{array}$} \\
\hline & & & $\begin{array}{l}\text { odległość do ośrod- } \\
\text { ka regionalnego } \\
\text { distance from } \\
\text { regional center }\end{array}$ & $\begin{array}{l}\text { wspólna tożsamość } \\
\text { historyczna } \\
\text { common historical } \\
\text { identity }\end{array}$ \\
\hline $\begin{array}{l}\text { pasmo Kamiennej } \\
\text { Ostrowiec Świętokrzyski, } \\
\text { Skarżysko-Kamienna, } \\
\text { Starachowice }\end{array}$ & 285 & $\begin{array}{l}\text { Małopolska } \\
\text { północna }\end{array}$ & Kielce / Radom & Kielce / Radom \\
\hline $\begin{array}{l}\text { Mazowsze rawskie } \\
\text { Łowicz (O), Rawa Mazo- } \\
\text { wiecka (O), Skierniewice }\end{array}$ & 215 & Mazowsze & Łódź / Warszawa & Warszawa \\
\hline $\begin{array}{l}\text { Mazury wschodnie } \\
\text { Ełk, Gołdap, Olecko, Pisz }\end{array}$ & 210 & $\begin{array}{l}\text { Prusy Ksią- } \\
\text { żęce }\end{array}$ & $\begin{array}{l}\text { Białystok / Łomża- } \\
\text { Ostrołęka / Olsztyn }\end{array}$ & Olsztyn \\
\hline $\begin{array}{l}\text { Chojnice } \\
\text { Chojnice (E), Człuchów (O) }\end{array}$ & 155 & $\begin{array}{l}\text { Prusy Królew- } \\
\text { skie } \\
\text { Kaszuby }\end{array}$ & Bydgoszcz-Toruń & Elbląg-Gdańsk \\
\hline $\begin{array}{l}\text { Brzeg } \\
\text { Brzeg, Namysłów }\end{array}$ & 135 & Śląsk & Opole / Wrocław & Opole / Wrocław \\
\hline Mielec & 135 & $\begin{array}{l}\text { Małopolska } \\
\text { południowa }\end{array}$ & Rzeszów / Tarnów & Rzeszów / Tarnów \\
\hline Chrzanów (W) & 125 & $\begin{array}{l}\text { Małopolska } \\
\text { południowa }\end{array}$ & $\begin{array}{l}\text { Katowice-Sosno- } \\
\text { wiec / Kraków }\end{array}$ & $\begin{array}{l}\text { Katowice-Sosno- } \\
\text { wiec / Kraków }\end{array}$ \\
\hline Olkusz (W) & 115 & $\begin{array}{l}\text { Małopolska } \\
\text { północna }\end{array}$ & $\begin{array}{l}\text { Katowice-Sosno- } \\
\text { wiec }\end{array}$ & $\begin{array}{l}\text { Katowice-Sosno- } \\
\text { wiec / Kraków }\end{array}$ \\
\hline Garwolin (W) & 110 & Mazowsze & Warszawa & Warszawa \\
\hline Racibórz (W) & 110 & $\begin{array}{l}\text { Śląsk } \\
\text { Niemcy, Śla- } \\
\text { zacy }\end{array}$ & $\begin{array}{l}\text { Katowice-Sosno- } \\
\text { wiec }\end{array}$ & $\begin{array}{l}\text { Katowice-Sosno- } \\
\text { wiec / Opole }\end{array}$ \\
\hline Bytów (E) & 80 & $\begin{array}{l}\text { Prusy Królew- } \\
\text { skie } \\
\text { Kaszuby }\end{array}$ & Słupsk & Elbląg-Gdańsk \\
\hline Nowe Miasto Lubawskie & 45 & $\begin{array}{l}\text { Prusy Królew- } \\
\text { skie }\end{array}$ & $\begin{array}{l}\text { Bydgoszcz-Torun / } \\
\text { Olsztyn }\end{array}$ & Bydgoszcz-Toruń \\
\hline Siemiatycze (E) & 45 & $\begin{array}{l}\text { Podlasie } \\
\text { Biatorusini }\end{array}$ & Siedlce & Białystok \\
\hline
\end{tabular}

Opracowanie własne / Author’s elaboration. 


\section{Budowa województw}

Według przyjętej procedury tworzenie województw polegało na łączeniu sąsiadujących ze sobą regionów. Wybór jednostek do powiązania uzależniono od kategorii wielkościowych ich ośrodków:

- ośrodki metropolitalne większe - nie są wiązane z innymi ośrodkami;

- ośrodki metropolitalne - nie są wiązane między sobą;

- ośrodki regionalne (zasady stosowane kolejno):

- są wiązane w województwa dwubiegunowe, jeśli liczba ludności takowego nie przekracza $2 \mathrm{mln}$;

- tworzą samodzielne województwa, gdy ludność przekracza 1 mln;

- są wiązane z ośrodkami metropolitalnymi.

Jeśli w świetle powyższych zasad możliwe było więcej niż jedno powiązanie, wybierano to, za którym przemawiało więcej czynników szczegółowych. Były nimi - podobnie jak przy budowie regionów - wzajemna bliskość ośrodków oraz wspólna tożsamość historyczna. Obowiązujący pozostaje warunek zwartości terytorialnej. W tabeli 4 wskazano możliwości powiązań ośrodków regionalnych.

W założeniach wstępnych przyjęto orientacyjny próg wielkościowy dotyczące województw - 1 mln ludności. Szczegółową jego wartość ustalono przez rozważanie możliwych do utworzenia najmniejszych jednostek - zależnie od połączeń regionów i pograniczy (tab. 5). Takie podejście pozwala uniknąć pominięcia któregoś z potencjalnych województw wskutek uznaniowego określenia wielkości granicznej.

W poniższej koncepcji próg wielkościowy wyznacza potencjalne województwo Gorzowa Wlkp. i Zielonej Góry, liczące 1,05 mln ludności. Pozostaje określić czynniki przyporządkowania pograniczy. Jako pierwszy przyjęto tożsamość historyczno-kulturową. W przypadkach nierozstrzygniętych na jego podstawie kryterium stanowiła równowaga wielkościowa: pogranicze włączano do mniejszej z sąsiadujących jednostek. W zestawieniu koncepcyjnych województw liczbę ludności podano w zaokrągleniu do 50 tys., stosownie do założenia o dopuszczalnych korektach granic powiatów. Podane nazwy województw mają charakter roboczy. Zgodnie ze wzorcem województwa policentrycznego starano się oddać złożoność projektowanych jednostek, nie rozszerzając jednak nazw do więcej niż dwóch członów. Wynikową koncepcję podziału przedstawiają tabela 6 i rycina 3. 
Tabela 4. Mniejsze regiony - możliwe powiązania Minor regions - possible mergers

\begin{tabular}{|c|c|c|c|c|}
\hline \multirow[b]{2}{*}{ Region } & \multirow{2}{*}{$\begin{array}{l}\text { Pogranicza } \\
\text { do przyłączenia } \\
\text { Border areas to } \\
\text { incorporate }\end{array}$} & \multirow{2}{*}{\begin{tabular}{|c|} 
Region \\
z pograni- \\
czami \\
- ludność \\
(tys.) \\
Region \\
with border \\
areas \\
- popula- \\
tion ('000)
\end{tabular}} & \multicolumn{2}{|c|}{$\begin{array}{l}\text { Możliwe powiązania z innymi regionami } \\
\text { według czynników } \\
\text { Possible mergers with other regions } \\
\text { in line with factors }\end{array}$} \\
\hline & & & $\begin{array}{l}\text { odległość między } \\
\text { ośrodkami regional- } \\
\text { nymi } \\
\text { distance between } \\
\text { regional center }\end{array}$ & $\begin{array}{l}\text { wspólna tożsamość } \\
\text { historyczna } \\
\text { common historical } \\
\text { identity }\end{array}$ \\
\hline Tarnów & Mielec & 1270 & Kraków, Rzeszów & Kraków, Rzeszów \\
\hline Olsztyn & $\begin{array}{l}\text { Mazury wschodnie, } \\
\text { Nowe Miasto Lubawskie }\end{array}$ & 1265 & Elbląg-Gdańsk & \\
\hline Kielce & pasmo Kamiennej & 1230 & Radom & Radom \\
\hline $\begin{array}{l}\text { Kalisz-Ostrów } \\
\text { Wlkp. }\end{array}$ & & 1155 & Łódź, Poznań & Łódź, Poznań \\
\hline Opole & Brzeg, Racibórz & 1110 & Wrocław & Wrocław \\
\hline Bielsko-Biała & & 980 & & Kraków \\
\hline Radom & pasmo Kamiennej & 980 & Kielce & Kielce, Lublin \\
\hline Białystok & Siemiatycze & 945 & Łomża-Ostrołęka & \\
\hline Częstochowa & & 890 & & Łódź \\
\hline Wałbrzych & & 860 & Legnica, Wrocław & Legnica, Wrocław \\
\hline Siedlce & Garwolin, Siemiatycze & 810 & & Lublin \\
\hline Legnica & & 800 & Wałbrzych, Wrocław & $\begin{array}{l}\text { Wałbrzych, Wrocław, } \\
\text { Zielona Góra }\end{array}$ \\
\hline Płock & & 780 & Włocławek & \\
\hline $\begin{array}{l}\text { Łomża-Ostro- } \\
\text { łęka }\end{array}$ & Mazury wschodnie & 720 & Białystok & \\
\hline Zielona Góra & & 595 & $\begin{array}{l}\text { Gorzów Wlkp., } \\
\text { Legnica }\end{array}$ & Legnica \\
\hline Gorzów Wlkp. & & 455 & $\begin{array}{l}\text { Szczecin, Zielona } \\
\text { Góra }\end{array}$ & Szczecin \\
\hline Koszalin & & 490 & Słupsk & Słupsk, Szczecin \\
\hline Włocławek & & 410 & $\begin{array}{l}\text { Płock, Bydgoszcz- } \\
\text { Toruń }\end{array}$ & \\
\hline Słupsk & Bytów & 325 & Koszalin & Koszalin \\
\hline
\end{tabular}

Opracowanie własne / Author's elaboration. 
Tabela 5. Wybór jednostki wyznaczającej próg wielkościowy

Selection of unit determining size threshold

\begin{tabular}{|l|l|c|}
\hline $\begin{array}{c}\text { Potencjalne województwo - powiązane regiony } \\
\text { Potential voivodship - regions merged }\end{array}$ & $\begin{array}{c}\text { Przyłączone pogranicza } \\
\text { Incorporated border areas }\end{array}$ & $\begin{array}{c}\text { Ludność (tys.) } \\
\text { Population ('000) }\end{array}$ \\
\hline Płock, Włocławek & & 1190 \\
Kalisz-Ostrów Wielkopolski & Brzeg, Racibórz & 1155 \\
Opole & & 1110 \\
Gorzów Wlkp., Zielona Góra & & $\mathbf{1 0 5 0}$ \\
Bielsko-Biała & & 980 \\
Częstochowa & Bytów & 890 \\
Koszalin, Słupsk & Garwolin, Siemiatycze & 815 \\
Siedlce & & 810 \\
\hline
\end{tabular}

Opracowanie własne / Author's elaboration.

Tabela 6. Koncepcja 20 województw

A Concept for 20 voivodships

\begin{tabular}{|c|c|c|c|}
\hline $\begin{array}{l}\text { Województwo } \\
\text { Voivodship }\end{array}$ & $\begin{array}{c}\text { Ośrodki wojewódzkie - } \\
\text { powiązane regiony } \\
\text { Voivodship centers - regions } \\
\text { merged }\end{array}$ & $\begin{array}{l}\text { Przyłączone pogranicza } \\
\text { Incorporated border areas }\end{array}$ & $\begin{array}{l}\text { Ludność } \\
\text { (tys.) } \\
\text { Population } \\
\text { ('000) }\end{array}$ \\
\hline Mazowieckie & Warszawa & Mazowsze rawskie, Garwolin & 3700 \\
\hline Śląsko-dąbrowskie & Katowice-Sosnowiec & & 3200 \\
\hline Cieszyńsko-krakowskie & Bielsko-Biała, Kraków & Chrzanów, Olkusz & 3050 \\
\hline Łódzko-częstochowskie & Częstochowa, Łódź & & 2700 \\
\hline Podlasko-lubelskie & Lublin, Siedlce & & 2450 \\
\hline Poznańskie & Poznań & & 2450 \\
\hline Pomorskie & Elbląg, Gdańsk & Bytów, Chojnice & 2300 \\
\hline Świętokrzyskie & Kielce, Radom & pasmo Kamiennej & 1950 \\
\hline Podkarpackie & Rzeszów & & 1850 \\
\hline Zachodniopomorskie & Koszalin-Słupsk, Szczecin & & 1750 \\
\hline Kujawsko-pomorskie & Bydgoszcz, Toruń & Nowe Miasto Lubawskie & 1700 \\
\hline Dolnośląskie & Legnica, Wałbrzych & & 1650 \\
\hline Podlasko-mazowieckie & Białystok, Łomża-Ostrołęka & Siemiatycze & 1450 \\
\hline Sądecko-tarnowskie & Tarnów & Mielec & 1250 \\
\hline Wrocławskie & Wrocław & & 1250 \\
\hline Warmińsko-mazurskie & Olsztyn & Mazury wschodnie & 1200 \\
\hline Kujawsko-mazowieckie & Płock, Włocławek & & 1200 \\
\hline Kaliskie & Kalisz-Ostrów Wlkp. & & 1150 \\
\hline Opolskie & Opole & Brzeg, Racibórz & 1100 \\
\hline Śląsko-lubuskie & Gorzów Wlkp., Zielona Góra & & 1050 \\
\hline
\end{tabular}

Opracowanie własne / Author’s elaboration. 


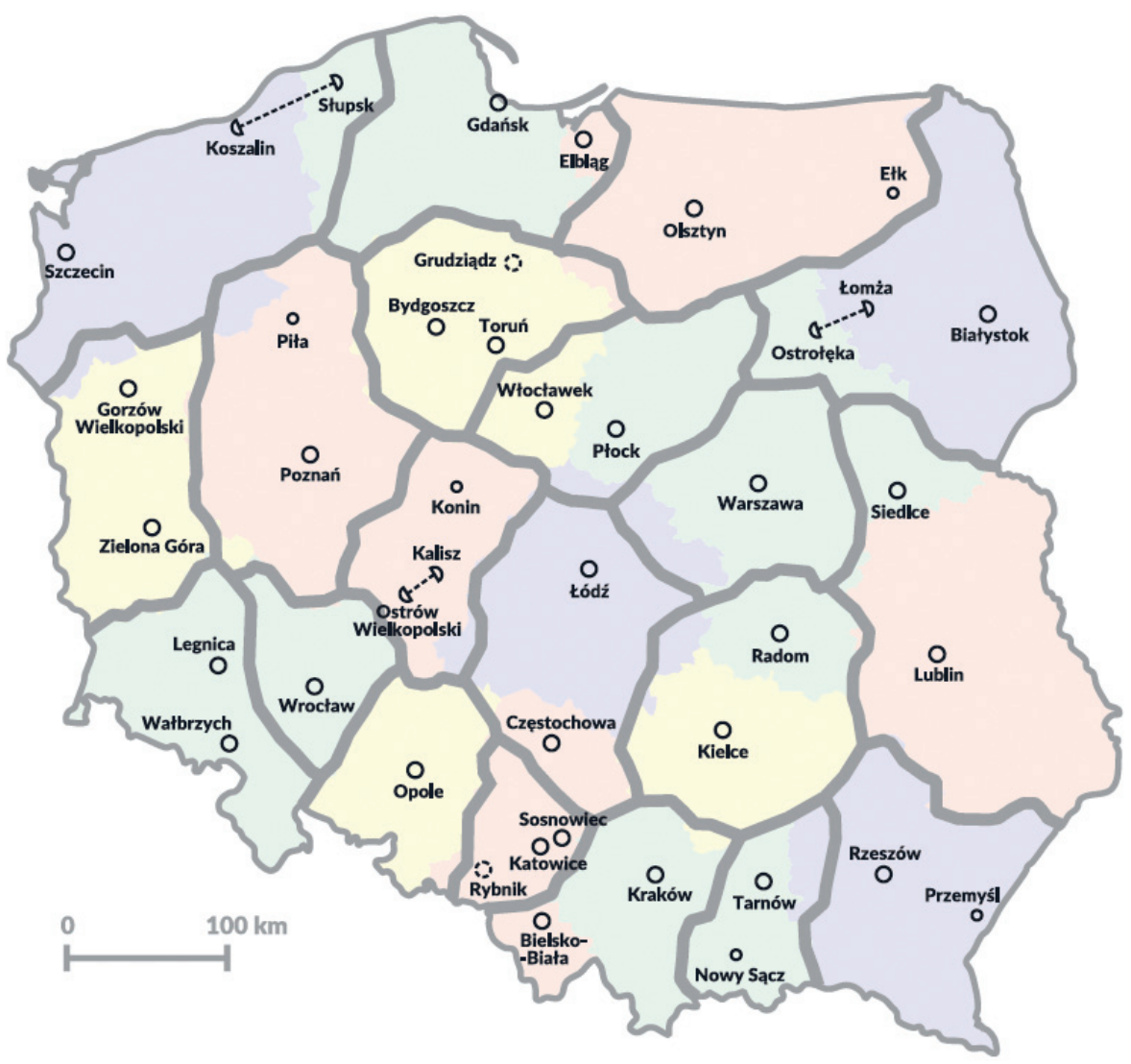

Ryc. 3. Koncepcja 20 województw

A Concept for 20 voivodships

Opracowanie własne na podstawie: / Author's elaboration based on: Zaborowski (2015b).

\section{Podsumowanie}

Przedstawiona koncepcja - umiarkowanie zwiększając obecną liczbę województw - wychodzi naprzeciw oczekiwaniom przeważającym w bieżącej debacie publicznej. Szczegółowe rozwiązania są jednak odmienne. Cechą charakterystyczną są dwubiegunowe układy ośrodków regionalnych: Białystok i ŁomżaOstrołęka, Gorzów Wlkp. i Zielona Góra, Kielce i Radom, Legnica i Wałbrzych, Płock i Włocławek. Z ośrodków regionalnych niemających takiego powiązania samodzielne województwa tworzą Kalisz-Ostrów Wlkp., Opole oraz Tarnów. Warto zwrócić uwagę, że w proponowanej koncepcji najmniejsze rozmiary mają 
odpowiedniki obecnych najmniejszych województw: lubuskiego i opolskiego, nie zaś jednostki dodane do układu.

W tym świetle należy widzieć przypadek Pomorza środkowego, które pozostaje poniżej progu przyjętego dla samodzielnego województwa. Stąd propozycja, by Koszalin i Słupsk potraktować jako zespół stanowiący równoważny ośrodek wojewódzki - obok Szczecina - w powiększonym województwie zachodniopomorskim. Ponadto cztery inne ośrodki regionalne zostają sparowane z sąsiednimi ośrodkami metropolitalnymi. Powiązania odmienne niż w obecnym układzie (np. Bielsko-Biała, Częstochowa) zmierzają do zachowania równowagi wielkościowej. Osiągnięto ją przez pomniejszenie największych województw. Obecnie mazowieckie liczy 5,3 mln ludności, śląskie - 4,6 mln; ich odpowiedniki w koncepcji - 3,7 i 3,2 mln. Iloraz wielkości między skrajnymi województwami w podziale obowiązującym wynosi 5,3, w rozpatrywanym $-3,5$.

Proponowany wzorzec województwa policentrycznego może mieć istotny wpływ na zrównoważenie struktury przestrzennej kraju i województw. Obecność dwóch równorzędnych ośrodków zapobiega koncentracji władzy w jednym miejscu, z korzyścią także dla pozostałych miast w województwie. W tym kontekście należałoby wręcz rozważyć, czy mniejsza liczba województw dwubiegunowych nie bardziej sprzyja rozwojowi policentrycznemu niż większa - jednostek monocentrycznych. Jednocześnie rozwiązanie to wychodzi naprzeciw społecznym animozjom wynikającym z odmiennego traktowania porównywalnych ośrodków. Pozwala też bardziej docenić tożsamość regionów, obecnie zagrożoną przez nieadekwatne użycie historycznych pojęć w nazwach województw.

Etapowanie prac - określenie najpierw regionów węzłowych dla ośrodków regionalnych - pozwoliło uniknąć przecięcia granicami województw układów osadniczych wokół dużych miast. Przykładem jest aglomeracja Bielska-Białej. Dodatkowo jej powiązanie z Krakowem znosi problematyczny podział pasma osadniczego pomiędzy tymi ośrodkami. Jakkolwiek rozważane województwo nie ma historycznego odpowiednika, tworzące je regiony łączy dziedzictwo monarchii habsburskiej oraz geograficzna specyfika Karpat. Cechy te nie wiążą Bielska-Białej i Cieszyna z konurbacją śląsko-dąbrowską. Podobne argumenty zwłaszcza o wspólnym zapleczu - można podać za powiązaniami Częstochowy i Łodzi oraz Elbląga i Gdańska.

Niniejsze opracowanie ma charakter studialny - opisuje próbę zastosowania procedury obiektywizującej tworzenie podziału terytorialnego. Metodyka jest uproszczona, podobnie jak ograniczony zestaw przyjętych czynników budowy regionów i województw. W procesie reformy na pewno należałoby wziąć pod uwagę także rzeczywiste związki funkcjonalne czy opinie lokalnych społeczności. Mimo powyższych uproszczeń, uzyskana koncepcja w dużym stopniu znosi główne wady cechujące obecny układ województw. Tym samym teza opracowania zdaje się być potwierdzona. Pozwala to wysunąć następujący wniosek do dalszej dyskusji o kierunkach korekty ustroju terytorialnego: ważne jest, by 
najpierw mówić o zasadach, a dopiero potem o szczegółowych rozwiązaniach na mapie. Obyśmy zdołali uniknąć powielania błędów poprzednich reform, o których trafnie pisze Stanisław Liszewski (1991, s. 64): „Oryginalność postępowania Polaków na początku lat dziewięćdziesiątych polega na zaczynaniu wielu ważnych spraw od końca."

\section{Piśmiennictwo / References}

Bober J., Hausner J., Izdebski J., Lachiewicz W., Mazur S., Nelicki A., Nowotarski B., Puzyna W., Surówka K., Zachariasz I., Zawicki M., 2013, Narastajace dysfunkcje, zasadnicze dylematy, konieczne działania. Raport o stanie samorządności terytorialnej w Polsce, Uniwersytet Ekonomiczny, Małopolska Szkoła Administracji Publicznej, Kraków.

Chojnicki Z., Czyż T., 1992, Region - regionalizm - regionalizacja, Ruch Prawniczy, Ekonomiczny i Socjologiczny, 2, s. 1-8.

Chojnicki Z., Czyż T., 2000, Nowa terytorialna organizacja Polski i uktad regionalny, Czasopismo Geograficzne, 71, 3-4, s. 261-277.

Czarnuch Z., 2004, Na tropie tożsamości ziemi torzymskiej, [w:] A. Toczewski (red.), Ziemia lubuska. Studia nad tożsamościa regionu, Muzeum Ziemi Lubuskiej, Zielona Góra, s. 71-98.

Czyż T., 2012, Poziom rozwoju społeczno-gospodarczego Polski w ujęciu subregionalnym, Przegląd Geograficzny, 84, 2, s. 219-236.

Czyżewska A., Kostarczyk A., 1989, Problematyka ochrony i kształtowania środowiska kulturowego Polski w planie przestrzennego zagospodarowania kraju, [w:] Przestrzeń kulturowa w planowaniu przestrzennym, Biuletyn KPZK PAN, 142, s. 57-75.

Gloger Z., 1903, Geografia historyczna ziem dawnej Polski, Spółka Wydawnicza Polska, Kraków.

Habuda A., Habuda L., 2014, Zasadniczy podziat terytorialny państwa. Między racjonalnym wyborem i gra zinstytucjonalizowanych interesów, Wrocławskie Studia Politologiczne, 16, s. 24-41.

Honka Z., 2014, Is a new administrative division reform necessary? A voice in the discussion on self-government reform, Środkowoeuropejskie Studia Polityczne, 3, s. 169-183.

Heffner K., 2009, Aglomeracje średniej wielkości jako bieguny wzrostu i obszary strategicznej interwencji w regionach międzymetropolitalnych, [w:] Potencjalne metropolie ze szczególnym uwzględnieniem Polski Wschodniej, Studia KPZK PAN, 125, s. 10-17.

Heffner K., 2015, Lokalizacja instytucji publicznych jako element polityki miejskiej i regionalnej, [w:] Lokalizacja instytucji publicznych jako element polityki miejskiej i regionalnej, Biuro Analiz i Dokumentacji, Kancelaria Senatu, Warszawa, s. 3-25.

Heffner K., Rochmińska A., 2000, Regionalizacja polityczno-administracyjna Polski. Geneza i wspótczesność - uwarunkowania uktadu, Przekształcenia Regionalnych Struktur Funkcjonalno-Przestrzennych, 5, Instytut Geograficzny UWr, Wrocław, s. 129-144.

Jałowiecki B., 1991, Spoteczne i polityczne aspekty terytorialnej organizacji kraju, Biuletyn KPZK PAN, 156, s. 35-50.

Jałowiecki B., 1997, Opinia, [w:] Reforma administracji publicznej „Państwo sprawne, przyjazne i bezpieczne", t. II, Elipsa, Warszawa, s. 25-34.

Kaczmarek T., 2005, Struktury terytorialno-administracyjne i ich reformy w krajach europejskich, Wydawnictwo Naukowe UAM, Poznań. 
Kołodziejski J., 1991, Podziat terytorialny kraju jako problem organizacji przestrzennej spoteczeństwa, gospodarki i państwa, Biuletyn KPZK PAN, 156, s. 7-34.

Kołodziejski J., Stasiak A., 1986, Koncepcja podziatu dwustopniowego - wariant podstawo$w y$, Biuletyn KPZK PAN, 128, s. 35-74.

Korcelli P., 2009, System osadniczy Polski - tendencje $i$ uwarunkowania przemian, [w:] T. Markowski (red.) Koncepcja przestrzennego zagospodarowania kraju a wizje i perspektywy rozwoju przestrzennego Europy, Studia KPZK PAN, 122, s. 30-42.

Kostarczyk A., 1997, Dziedzictwo kulturowe regionów Polski, [w:] E. Wysocka, M. Konopka (red.), Polskie regiony. Podstawy kulturowe regionalizacji Polski, Krajowy Ośrodek Dokumentacji Regionalnych Towarzystw Kultury, Ciechanów, s. 21-25.

Kowalczyk A., 2000, Reforma podziatu terytorialnego Polski w 1999 roku - krytyczna analiza mechanizmu jej wprowadzania, [w:] S. Ciok, D. Ilnicki (red.), Regionalny wymiar integracji europejskiej, Przekształcenia Regionalnych Struktur Funkcjonalno-Przestrzennych, III/1, Instytut Geograficzny UWr, Wrocław, s. 87-100.

Lijewski T., 1984, Odpowiedź na ankietę, [w:] Podziat administracyjny kraju. Poglady i opinie, Biuletyn KPZK PAN, 126, s. 65-75.

Lijewski T., 2002, Nowy podział administracyjny a dostępność ośrodków administracji, Prace Komisji Geografii Komunikacji PTG, VIII, Wydział Ekonomii UR, Warszawa-Rzeszów, s. 5-14.

Lijewski T., 2003, Koncentracja ośrodków aktywności gospodarczej w Polsce w świetle list 500 firm, Przegląd Geograficzny, 75, 3, s. 433-447.

Liszewski S., 1991, Podziat administracyjny kraju. Założenia i kryteria, [w:] Koncepcje regionalnej organizacji kraju, Biuletyn KPZK PAN, 156, s. 63-77.

Łysoń P., 1998, Projekt kształtu terytorialnego 13 dużych województw-regionów, Samorząd Terytorialny, 1, s. 48-63.

Miszczuk A., 2003, Regionalizacja administracyjna III Rzeczpospolitej. Koncepcje teoretyczne a rzeczywistość, Wydawnictwo UMCS, Lublin.

Narodowy Spis Powszechny 2011, 2011, Główny Urząd Statystyczny, Warszawa.

Nelicki A., 2001, Ksztattowanie się struktur administracji powiatowej i wojewódzkiej, [w:] G. Gorzelak, B. Jałowiecki, M. Stec (red.), Reforma terytorialnej organizacji kraju: dwa lata doświadczeń, Scholar, Warszawa, s. 51-72.

Piotrowski D., 2004, Rozwój peryferyjnego ośrodka o znaczeniu regionalnym a zmiany struktur funkcjonalno-przestrzennych na przykładzie Suwałk, Wyższa Szkoła Rozwoju Lokalnego, Żyrardów.

Piskozub A., 1987, Dziedzictwo polskiej przestrzeni. Geograficzno-historyczne podstawy struktur przestrzennych ziem polskich, Zakład Narodowy im. Ossolińskich, Wrocław.

Plit J., 2015, Regionalizacja wspótczesnych krajobrazów historyczno-kulturowych Polski, Prace Komisji Krajobrazu Kulturowego PTG, 27, s. 79-94.

Sługocki J., 1997, Pozycja prawnoustrojowa regionu. Dylematy regionalizacji w Polsce, Studia i Materiały Wyższej Szkoły Pedagogicznej, 115, Wyższa Szkoła Pedagogiczna, Olsztyn.

Sokołowski D., 2011, Centralność większych miast Polski. Rola czynnika administracyjnego i globalizacji, Przekształcenia regionalnych struktur funkcjonalno-przestrzennych, 2, Instytut Geografii i Rozwoju Regionalnego, UWr, Wrocław, s. 11-24.

Sokołowski D., 2014, Niektóre uwarunkowania korekty podziału Polski na województwa, Przegląd Geograficzny, 86, 4, s. 567-590.

Szczepkowski J., 1991, Projekt podziatu administracyjnego Polski, [w:] Koncepcje regionalnej organizacji kraju, Biuletyn KPZK PAN, 156, s. 117-132.

Śleszyński P., 2007, Gospodarcze funkcje kontrolne w przestrzeni Polski, Prace Geograficzne, IGiPZ PAN, 213. 
Śleszyński P., 2015, W sprawie optymalnego podziatu terytorialnego Polski: zastosowanie analizy grawitacyjnej, Przegląd Geograficzny, 87, 2, s. 343-359.

Ustawa z dnia 24 lipca 1998 r. o wprowadzeniu zasadniczego trójstopniowego podziału terytorialnego państwa, Dz.U. z 1998 r. Nr 96, poz. 603, Nr 104, poz. 656; z 1999 r. Nr 101, poz. 1182; z 2001 r. Nr 45, poz. 497.

Wendt J., 2001, Geografia władzy w Polsce, Wydawnictwo UG, Gdańsk.

Wróbel A., 1984, Odpowiedź na ankietę, [w:] Podziat administracyjny kraju. Poglady $i$ opinie, Biuletyn KPZK PAN, 126, s. 164-166.

Wróbel A., 1986, Wnioski w sprawie przysztego podziału administracyjnego Polski, Biuletyn KPZK PAN, 128, s. 75-109.

Wysocka E., Konopka M. (red.), 1997, Polskie regiony. Podstawy kulturowe regionalizacji Polski, Krajowy Ośrodek Regionalnych Towarzystw Kultury, Ciechanów.

Zaborowski Ł., 2013, Podziat kraju na województwa. Próba obiektywizacji, Scholar, Warszawa.

Zaborowski Ł., 2014, Sieć ośrodków regionalnych w Koncepcji Przestrzennego Zagospodarowania Kraju 2030. Próba uporzaddkowania wedtug czynników wielkości i odlegtości, Przegląd Geograficzny, 86, 4, s. 591-620.

Zaborowski Ł., 2015a, Lokalizacja instytucji publicznych jako element polityki regionalnej i miejskiej, [w:] Lokalizacja instytucji publicznych jako element polityki miejskiej i regionalnej, Biuro Analiz i Dokumentacji, Kancelaria Senatu, Warszawa, s. 26-86.

Zaborowski Ł., 2015b, Przestanki i możliwości korekty podziału terytorialnego państwa na szczeblu województw w świetle rozmieszczenia głównych ośrodków miejskich, referat na zebranie naukowe Zakładu Geografii Miast i Ludności IGiPZ PAN w Warszawie, 25.09.2015 r.

Ziobrowski Z., Trafas K., Węcławowicz T., Komeda J., 1991, Koncepcja podziału terytorialnego kraju, [w:] Koncepcje regionalnej organizacji kraju, Biuletyn KPZK PAN, 156, s. 89-116.

Zioło Z., 1992, Głos w dyskusji, [w:] Regionalizacja w Polsce w świetle doświadczeń zachodnioeuropejskich, Biuletyn KPZK PAN, 160, s. 73-78.

[Wpłynęło: styczeń; poprawiono: maj 2016 r.]

\section{ŁUKASZ ZABOROWSKI}

\section{AN ATTEMPT AT RESTRUCTURING POLAND'S VOIVODSHIP SYSTEM ON THE BASIS OF A NETWORK OF REGIONAL CENTRES}

Efforts to remake a country's territorial division start with a choice of constituent-elements assumed to be indivisible. There then follows a selection of centres that determine the number of units at a particular level. Units are formed by attaching the constituent-elements to the centres. In the work described in this paper, relating to Poland, "regions" were first formed from the county-level units (i.e. the poviats) included within the country's present system of territorial administration. A reworked concept for the level of the Polish voivodship (administrative region) was then elaborated by a process of merging the aforementioned regions. In "building" these regions account needs to be taken of both the real-world settlement pattern and the territorial heritage, notwithstanding the way in which these two main factors may give 
contradictory indications. A further opinion holds that present-day socio-economic linkages should offer the basis upon which administrative regions are created. However, such functional ties are in fact much influenced by the territorial division that is present, to the extent that their use as a crucial criterion in adjustment would seem to involve the mistaking of cause and effect. In the work described here, it was rather assumed that a regional centre is the optimal location for major public services for the surrounding region. This in turn speaks for the selection of rail/road distance as a delimiting factor, along with reference to the historical cohesion of a given unit. A simplified division of Poland into historical provinces is presented in Fig. 1.

The list of regional centres, as broken down by size categories, is shown in Table 1 . Some centres are assigned to two historical provinces on account of a border location. Moreover, some centers have minority ethnic groups assigned to them, in line with their traditional regions. In cases in which these main criteria for forming regions were not sufficient, auxiliary factors were applied, like the protection of the historical identity of a single county (T); relations in settlement structure at subregional level (O); and other relations at regional level (I). Moreover, the regions taking shape were made subject to certain general restrictions relating to: territorial compactness $(\mathrm{Z})$; the assignment of an ethnic group to its regional centre only (E); and size limitation for the region of a major metropolitan centre $(\mathrm{W})$. The result is a map of regions serving as the constituent-elements for the building of voivodships (Fig. 2, Table 2). Border areas remaining unassigned are as listed in Table 3.

Voivodships were created by merging regions, in line with rules dependent on characteristics of their centres. To ensure balance in the system, major metropolitan centres are not merged with other centres. Regular metropolitan centres are not merged with one another either. Regional centres are only merged into dual complexes where the unit being created has a population below 2 million. If a centre lacks such a potential merger candidate it forms a separate voivodship, on the condition that the population achieved exceeds 1 million (as a threshold derived from the present division). Only after all the foregoing solutions are exhausted are regional centres merged with neighbouring metropolitan centres. Possible mergers for smaller regions are shown in Table 4.

The resulting concept - presented in Table 6 and on Fig. 3 - corresponds with postulates being advanced in current public debate in Poland. However, the detailed solutions are different. Size balance in the system was achieved mainly by diminishing the largest existing units. At present, Mazowieckie voivodeship has a population of 5.3 million, while Śląskie has 4.6 million people. The proposed equivalents would have populations reduced to 3.7 and $3.2 \mathrm{M}$ respectively. At the other end of the scale, four of the newly-created units exceed the smallest existing voivodships (Lubuskie and Opolskie) in size. The size quotient between the largest and smallest units in the existing division thus amounts to 5.3, while the presented concept would be limited to 3.5. The proposed model for polycentric voivodships aims to balance spatial structures at both national and regional levels. The coexistence of two main centres can help prevent power concentrating in one place, with all other towns benefiting in the process. In this light, a smaller number of multipolar voivodships may prove better able to foster polycentric development than a greater number of monocentric units. 